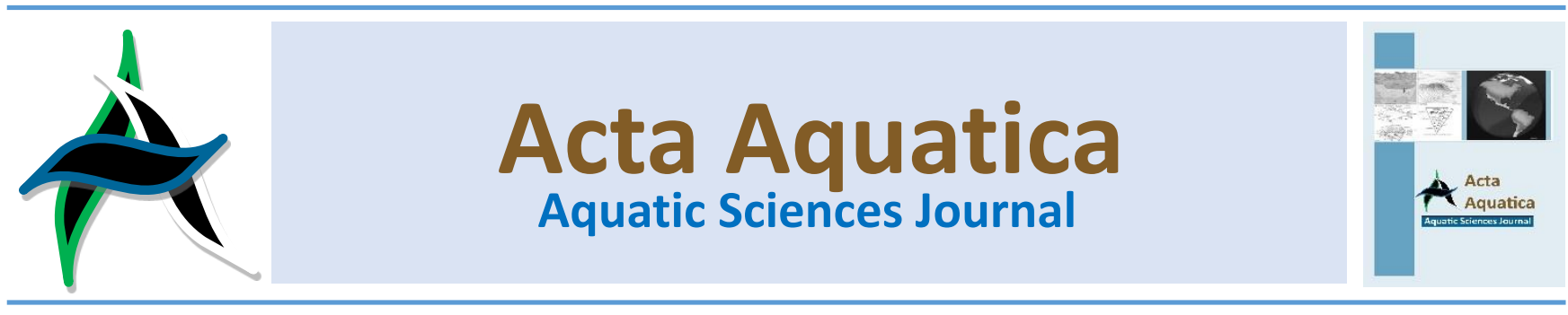

\title{
Pengaruh dosis hormon rGH dan tiroksin dalam pakan terhadap pertumbuhan dan kelangsungan hidup benih ikan koi (Cyprinus carpio, L)
}

\section{The effect of rGH and thyroxine hormone dosage in feed on the growth and survival rate of koi larvae (Cyprinus carpio, L)}

\author{
Sutiana ${ }^{a *}$, Erlangga ${ }^{a, b}$ dan Zulfikar ${ }^{a, b}$ \\ a Program Studi Budidaya Perairan, Fakultas Pertanian, Universitas Malikussaleh \\ ${ }^{b}$ Program Studi Ilmu Kelautan, Fakultas Pertanian, Universitas Malikussaleh
}

\begin{abstract}
Abstrak
Pertumbuhan yang relatif lama menjadi salah satu kendala dalam komoditas perdagangan khususnya ikan koi. Kebutuhan pakan yang sangat tinggi sangat menjadi masalah bagi para pembudidaya ikan koi. Salah satu cara yang bisa dilakukan untuk mencapai tujuan tersebut adalah dengan memberikan hormon tiroksin dan hormon rGH ke dalam makanannya agar dapat memberikan percepatan pertumbuhan. Penelitian ini dilaksanakan pada bulan Februari-Maret 2016 yaitu di Laboratorium Hatchery dan Teknologi Budidaya Perairan Program Studi Budidaya Perairan Fakultas Pertanian Universitas Malikussaleh. Penelitian ini bertujuan untuk mengetahui pengaruh pemberian hormon tiroksin dan hormon rGH melalui metode oral dengan dosis yang berbeda terhadap pertumbuhan dan kelangsungan hidup benih ikan koi (Cyprinus carpio L). Penelitian ini menggunakan metode eksperimental dengan menggunakan rancangan acak lengkap (RAL) non-faktorial dengan empat perlakuan tiga kali ulangan. Hasil penelitian dengan pemberian hormon tiroksin dan hormon $\mathrm{rGH}$ dengan dosis yang berbeda tidak menunjukkan pengaruh yang nyata terhadap pertumbuhan bobot, panjang, kelangsungan hidup dan konversi pakan. Perlakuan $D$ dengan dosis $T_{4} 25 \mathrm{mg} / \mathrm{kg}$ dan hormon $\mathrm{rGH} 2,5 \mathrm{mg} / \mathrm{kg}$ pakan menghasilkan nilai pertumbuhan bobot sebesar $0,60 \mathrm{gr}$ dan panjang $0,54 \mathrm{~cm}$. Nilai kelangsungan hidup pada setiap perlakuan dengan nilai sebesar $100 \%$. Nilai konversi pakan terbaik pada perlakuan $D$ sebesar 1,92 . Nilai kisaran kualitas air selama penelitian yaitu suhu $27-28^{\circ} \mathrm{C}, \mathrm{pH} 7.0-$ 7.9, DO 5.9-6.9 ppm dan amonia 0,0359-0,1946 ppm.
\end{abstract}

\begin{abstract}
Relatively slow growth becomes one of the obstacles in trading commodities, especially on koi fish. A high feed requirement becomes a problem for the koi fish farmers. One way that can be done to achieve that goal is by giving thyroxin hormone and $\mathrm{rGH}$ hormone into its feed in order to deliver a growth acceleration. This research was conducted in February - March 2016 in the Hatchery and Aquaculture Technology Laboratory at the department of Aquaculture, Agriculture Faculty, Malikussaleh University. This research aimed to determine the effect of thyroxin hormone and RGH hormone through oral methods with different doses on the growth and the survival of koi (Cyprinus carpio L). This research used experimental method using completely randomized design (CRD) non-factorial with four treatments of three replications. The results of the research showed that giving different doses of thyroxin hormone and $\mathrm{rGH}$ hormone had no significant effect on the growth in weight, length, survival and feed conversion. Treatment $D$ that had a dose of $25 \mathrm{mg} / \mathrm{kg}$ T4 and $\mathrm{rGH}$ hormone of $2,5 \mathrm{mg} / \mathrm{kg}$ in the feed produce the growth in weight of $0.60 \mathrm{gr}$ and length of $0.54 \mathrm{~cm}$. The value of survival in each treatment is $100 \%$. The best-feed conversion value in treatment $D$ is 1.92 . Value range of the water quality during the research is at the temperature of $27-28^{\circ} \mathrm{C}, \mathrm{pH}$ of 7.0 - 7.9, DO of 5.9 $-6.9 \mathrm{ppm}$ and ammonia ranges from 0.0359 to $0.1946 \mathrm{ppm}$.
\end{abstract}

Keywords: koi; rGH hormone; thyroxin hormone; growth

\section{Pendahuluan}

\footnotetext{
* Korespondensi: Program Studi Budidaya Perairan, Fakultas Pertanian, Universitas Malikussaleh. Kampus utama Reuleut, Kecamatan Muara Batu, Kabupaten Aceh Utara, Provinsi Aceh, Indonesia.

Tel: +62-645-41373 Fax: +62-645-59089.

e-mail: tianatina92@gmail.com
}

Ikan hias merupakan salah satu komoditi perikanan yang potensial dalam menghasilkan devisa bagi negara dan mensejahterakan masyarakat perikanan (pembudidaya). Pada saat ini peminat ikan hias terus bertambah dan semakin menyebar keseluruh lapisan masyarakat. Meskipun kemampuan 
daya belinya bervariasi, masyarakat perkotaan di Indonesia melengkapi rumahnya dengan akuarium-akuarium yang diisi beragam ikan hias salah satunya ikan koi (Bachtiar, 2002).

Ikan koi sampai saat ini masih menjadi salah satu komoditas perdagangan yang cukup tinggi dalam bidang perikanan. Oleh karena itu, kehadiran koi di tengah keluarga selalu berdampak positif, artinya apabila dipelihara dalam skala besar dapat digunakan sebagai mata pencaharian sekaligus dapat menciptakan lapangan pekerjaan baru. Sedangkan bila dipelihara dalam skala kecil layaknya ikan hias, koi dapat dijadikan sarana rekreasi atau menyalurkan hobi seseorang dengan mengamati keindahan dan lenggak-lenggoknya dalam aquarium (Effendy dan Hersanto, 1993).

Dengan meningkatnya permintaan terhadap ikan koi, maka diperlukan teknik budidaya untuk meningkatkan pertumbuhannya agar lama waktu proses produksi dapat dipersingkat. Kebutuhan pakan yang sangat tinggi sangat menjadi masalah bagi para pembudidaya ikan koi. Pakan merupakan input produksi budidaya yang sangat menentukan tingkat pertumbuhan ikan, namun sebagian pakan yang diberikan hanya $25 \%$ yang dikonversi sebagai hasil produksi dan yang lainnya terbuang sebagai limbah (Maharani, 2012 dalam Ihsanudin, 2014). Hal ini sangat mempengaruhi biaya dan waktu yang diperlukan dalam usaha budidaya, maka dari itu pemanfaatan pakan secara maksimal dan penyerapan pakan yang baik sangat dapat mempengaruhi pertumbuhan dan kelangsungan hidup ikan.

Untuk memenuhi kebutuhan masyarakat terhadap ikan koi maka dibutuhkan tehnik budidaya untuk meningkatkan laju pertumbuhan agar proses produksi dapat dipersingkat. Salah satu cara yang bisa dilakukan untuk mencapai tujuan tersebut adalah dengan memberikan hormon tiroksin dan hormon $\mathrm{rGH}$ ke dalam makanannya. Hormon tiroksin telah dilaporkan dapat meningkatkan laju pertumbuhan ikan melalui peningkatan laju metabolisme, efisiensi pakan dan retensi protein. Kemudian hormon $\mathrm{rGH}$ juga dapat memberikan percepatan pertumbuhan pada ikan karena tersusun atas asam amino yang dapat digunakan untuk memacu pertumbuhan ikan. Pemberian dengan metode oral terbukti dapat mempercepat pertumbuhan kultivan dikarenakan kedua hormon yang tercampur dalam pakan lebih dapat mudah masuk kedalam tubuh ikan.

Berdasarkan hal tersebut perlu dilakukan suatu penelitian mengenai kelebihan dari masing-masing pemberian hormon tersebut. Dengan demikian hormon tiroksin mempunyai kelebihan yaitu mampu mengatur metabolisme pada ikan dan memacu laju pertumbuhan, mampu meningkatkan nafsu makan ikan, menambah berat tubuh dan meningkatkan kecepatan absorbsi pada ikan. Sedangkan hormon rGH mempunyai kelebihan yaitu untuk meningkatkan kecepatan tumbuh ikan hampir $100 \%$, ikan yang dihasilkan juga memiliki ukuran yang seragam dan dapat meningkatkan laju pertumbuhan ikan 30 kali lebih cepat dari ikan normal.

\section{Bahan dan metode}

\subsection{Waktu dan tempat}

Penelitian ini akan dilaksanakan pada bulan 1 Februari sampai 15 Maret 2016 yaitu di Laboratorium Hatchery dan Teknologi Budidaya Perairan Program Studi Budidaya Perairan Fakultas Pertanian Universitas Malikussaleh.
Tabel 1.

Bahan dan alat yang digunakan

\begin{tabular}{ll}
\hline \multicolumn{1}{c}{ Bahan/alat } & \multicolumn{1}{c}{ Fungsinya } \\
\hline Benih ikan koi & Biota uji \\
Hormon tiroksin $\left(\mathrm{T}_{4}\right)$ & Bahan uji \\
Hormon rGH & Bahan uji \\
Pakan pellet & Pakan ikan \\
Air tawar & Media pemeliharaan \\
PBS dan NaCL & Untuk melarutkan hormon \\
Aquarium & Wadah pemeliharaan ikan \\
Aerasi & Untuk mensuplai oksigen \\
Saringan & Untuk pengambilan biota uji \\
pH meter & Untuk pengukuran pH air \\
DO meter & Mengukur oksigen terlarut \\
Timbangan analitik & Untuk menimbang suatu bahan dengan ketelitian \\
& yang tinggi. \\
Penggaris & Untuk mengukur panjang biota uji \\
Kamera & Untuk dokumentasi \\
Thermometer & Untuk mengukur suhu air \\
Alat tulis & Untuk menulis data \\
Semprot & Untuk menyemprot hormon ke pakan \\
Spectrofotometer & Untuk mengukur amoniak \\
\hline
\end{tabular}

\subsection{Metode dan rancangan penelitian}

Metode penelitian dilakukan dengan metode eksperimental. Rancangan penelitian yang akan digunakan adalah rancangan acak lengkap (RAL) non faktorial yang terdir dari 4 perlakuan dan 3 kali ulangan. Adapun perlakuan tersebut adalah sebagai berikut:

Perlakuan $\mathrm{A}=$ Kontrol, tanpa pemberian hormon tiroksin dan hormon rGH.

Perlakuan $\mathrm{B}=$ Pelet dengan $\mathrm{T}_{4} 15 \mathrm{mg} / \mathrm{kg}$ dan hormon $\mathrm{rGH} 1,5$ $\mathrm{mg} / \mathrm{kg}$ pakan

Perlakuan $\mathrm{C}=$ Pelet dengan $\mathrm{T}_{4} 20 \mathrm{mg} / \mathrm{kg}$ dan hormon $\mathrm{rGH} 2$ $\mathrm{mg} / \mathrm{kg}$ pakan

Perlakuan $\mathrm{D}=$ Pelet dengan $\mathrm{T}_{4} 25 \mathrm{mg} / \mathrm{kg}$ dan hormon $\mathrm{rGH} 2,5$ $\mathrm{mg} / \mathrm{kg}$ pakan.

Penelitian ini mengacu pada penelitian Ihsanudin et al. (2014) dan Zairin et al. (2005) yang menggunakan dosis yang terbaik yaitu tiroksin $20 \mathrm{mg} / \mathrm{kg}$ pakan dan dosis $\mathrm{rGH} 2 \mathrm{mg} / \mathrm{kg}$ pakan.

\subsection{Prosedur penelitian}

\subsubsection{Persiapan wadah}

Wadah yang digunakan dalam penelitian ini adalah akuarium yang berukuran $50 \times 30 \times 30 \mathrm{~cm}^{3}$ sebanyak 12 unit. Masing-masing wadah tersebut dibersihkan terlebih dahulu kemudian dikeringkan. Selanjutnya wadah diisi air sebanyak 25 liter/wadah lalu dipasangkan aerasi.

\subsubsection{Biota uji}

Ikan yang akan digunakan pada penelitian ini adalah benih ikan koi yang ukuran panjang dan beratnya sama yang berukuran 2-3 cm yang berumur 2 bulan dengan padat tebar 10 ekor /wadah. Ikan koi yang akan digunakan diaklimatisasi terlebih dahulu selama 24 jam agar ikan dapat beradaptasi dengan lingkungan penelitian. Selama proses aklimatisasi ikan tetap diberikan pakan pelet biasa yang tidak mengandung hormon.

\subsection{Bahan dan alat}

Bahan dan alat yang digunakan dalam pelaksanaan penelitian ini dapat dilihat pada Tabel 1. 


\subsubsection{Metode pencampuran hormon tiroksin $\left(T_{4}\right)$ dan $r G H$ pada pakan}

Sebelum dilakukan penyemprotan pada pakan, terlebih dahulu hormon tiroksin /Thyrax (levothyroxine sodium) dengan kandungan bahan aktif 0,1 mg per tablet dilakukan penggerusan sampai halus lalu ditimbang sesuai dosis perlakuan dan dilarutkan dengan larutan infus $(\mathrm{NaCl})$ sebanyak $100 \mathrm{ml}$ dan kemudian diaduk hingga merata. Setelah itu hormon $\mathrm{rGH}$ yang berbentuk serbuk diambil sebanyak dosis setiap perlakuan lalu dilarutkan dengan larutan PBS sebanyak $10 \mathrm{ml}$. Campuran hormon tersebut disemprotkan ke pakan hingga merata sesuai dosis perlakuan, kemudian pakan diangin- anginkan hingga kering barulah diberikan pada ikan. Penyimpanan pakan dilakukan didalam plastik dibungkus dengan rapat agar udara tidak masuk ke dalam pakan supaya hormon tidak terurai.

\subsubsection{Pemberian pakan yang mengandung hormon tiroksin dan $r G H$}

Pemberian pakan dilakukan 3 kali sehari yaitu pagi pukul 08.00 WIB, siang pukul 12.00 WIB dan sore hari pukul 16.00 WIB. Pemberian pakan sebanyak $5 \%$ dari bobot tubuh.

\subsubsection{Pemeliharaan ikan koi}

Pemeliharaan ikan koi dilakukan selama 45 hari. Selama masa pemeliharaan, kualitas air harus selalu diperhatikan agar kondisi ikan dalam keadaan baik. Penyiponan dilakukan setiap hari sebanyak $25 \%$ dari jumlah awal sebelum pemberian pakan dan dilakukan pengisian air kembali seperti semula, kemudian pergantian air seluruhnya dilakukan setiap tujuh hari sekali.

\subsection{Parameter penelitian}

Parameter penelitian antara lain pertumbuhan ikan koi, laju pertumbuhan harian, kelangsungan hidup, dan konversi pakan.

\subsubsection{Pertumbuhan ikan koi}

Pertambahan bobot dan panjang total ikan diamati setiap 7 hari sekali, pada pagi hari melalui pengamatan sampel seluruh ikan untuk melihat pertumbuhan bobot dan mengukur panjang total ikan. Pengukuran bobot dan panjang dihitung menggunakan rumus (Effendie, 1979), yaitu:

\section{$\mathrm{W}=\mathrm{Wt}-\mathrm{Wo}$}

Keterangan:

W : pertumbuhan berat rata- rata ikan $(\mathrm{mg})$

Wt : pertambahan berat rata - rata padaakhir $(\mathrm{mg})$

Wo : pertambahan berat rata - rata pada awal $(\mathrm{mg})$

Keterangan:

$$
L=L t-L_{0}
$$

$\mathrm{L} \quad$ : pertumbuhan panjang $(\mathrm{cm})$

Lt : panjang ikan pada waktu akhir $(\mathrm{cm})$

$\mathrm{L}_{0} \quad$ : panjang ikan pada waktu awal $(\mathrm{cm})$

\subsubsection{Laju pertumbuhan harian (growth rate)}

Untuk mengetahui pengaruh perlakuan terhadap ikan koi, maka pada akhir masa penelitian dilakukan evaluasi yang meliputi laju pertumbuhan harian (Huisman, 1976), Laju pertumbuhan dihitung dengan rumus yaitu:

$$
\alpha=\left\{\sqrt[t]{\frac{W t}{W 0}}-1\right\} x 100
$$

Keterangan:

$\alpha \quad$ : laju pertumbuhan harian / bobot tubuh per hari (\%)

Wt : bobot rata-rata ikan akhir penelitian (gr)

$W_{0}$ : bobot rata-rata ikan awal penelitian (gr)

$\mathrm{t}$ : lama pemeliharaan selama penelitian

\subsubsection{Kelangsungan hidup (survival rate)}

Pengamatan jumlah ikan yang hidup pada awal dan akhir penelitian dan dilakukan dengan cara menghitung seluruh jumlah ikan yang masih hidup yaitu dihitung dengan menggunakan rumus Effendie (1979):

Keterangan :

$$
\mathrm{SR}=\frac{N t}{N o} \times 100 \%
$$

SR : kelangsungan hidup (\%)

$\mathrm{Nt}$ : jumlah ikan hidup pada akhir penelitian (ekor)

No : jumlah ikan hidup pada awal penelitian (ekor)

\subsubsection{Konversi pakan (FCR)}

Konversi pakan atau Feed Conversion Rate (FCR) adalah jumlah pakan yang dihabiskan. Rumusnya sebagai berikut:

$$
\mathrm{FCR}=\frac{\mathrm{F}}{(\mathrm{Wt}+\mathrm{Wd})-\mathrm{W} 0} \times 100
$$

Keterangan :

FCR : konversi pakan (gr)

$\mathrm{F} \quad$ : jumlah pakan yang diberikan selama pemeliharaan (gr)

$\mathrm{W}_{0}$ : berat ikan saat awal penelitian (gr)

Wt : berat ikan akhir penelitian (gr)

Wd : bobot ikan yang mati (gr)

\subsubsection{Parameter kualitas air}

Pengukuran kualitas air dilakukan setiap hari sekali yaitu pagi hari. Parameter yang diamati antara lain: $\mathrm{pH}$, suhu, DO, sedangkan amoniak diukur tiga kali selama penelitian yaitu pada awal penelitian, pertengahan penelitian dan akhir penelitian.

\subsection{Analisis data}

Menurut Gomez dan Gomez (1995) model matematika dari Rancangan Acak Lengkap (RAL) non-faktorial yang digunakan adalah sebagai berikut:

$$
Y i j=\mu+\tau i+\varepsilon i j
$$

Keterangan :

$\mathrm{Yij}_{\mathrm{ij}}$ hasil pengamatan pengaruh dosis hormon tiroksin dan hormon $\mathrm{rGH}$

$\mu=$ rataan Umum

$\tau i=$ pengaruh masing-masing perlakuan ke-i

$\varepsilon i j=$ efek kesalahan (galat) pada perlakuan ke-i dalam ulangan ke-j

Analisis data dilakukan dengan menggunakan software Statistical Package for Sosial Science (SPSS) versi 16.0. Data yang diperoleh dibuat dalam bentuk tabel dan grafik, selanjutnya dianalisis dengan uji $\mathrm{F}$ apabila diantara perlakuan menunjukkan 
pengaruh yang nyata dimana $F_{\text {hitung }}>F_{\text {tabel, }}$ maka dilanjutkan dengan uji BNT/Beda Nyata Terkecil.

\section{Hasil dan pembahasan}

\subsection{Pertumbuhan ikan koi}

\subsubsection{Pertumbuhan bobot ikan koi}

Berdasarkan hasil pengukuran selama penelitian terhadap pertumbuhan berat dengan penambahan hormon yang dicampurkan kedalam pakan dapat dilihat pada masing-masing perlakuan disajikan pada Gambar 1 dibawah ini.

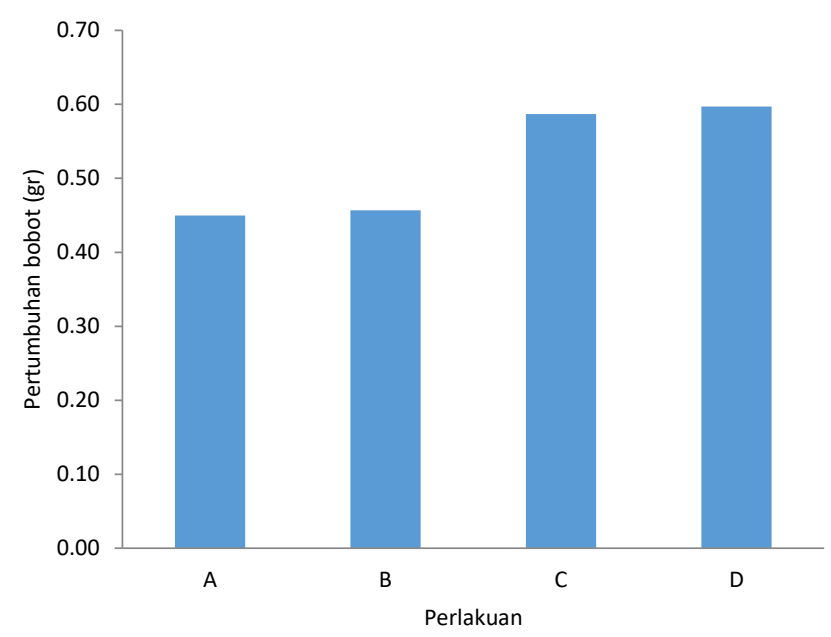

Gambar 1. Pertumbuhan bobot ikan koi.

Keterangan:

$A=$ kontrol

$B=T_{4} 15 \mathrm{mg} / \mathrm{kg}, \mathrm{rGH} 1,5 \mathrm{mg} / \mathrm{kg}$

$\mathrm{C}=\mathrm{T}_{4} 20 \mathrm{mg} / \mathrm{kg}, \mathrm{rGH} 2 \mathrm{mg} / \mathrm{kg}$

$\mathrm{D}=\mathrm{T}_{4} 25 \mathrm{mg} / \mathrm{kg}, \mathrm{rGH} 2,5 \mathrm{mg} / \mathrm{kg}$

Penambahan bobot rata-rata tertinggi terjadi pada perlakuan $D$ dengan penambahan hormon $T_{4} 25 \mathrm{mg} / \mathrm{kg}$ dan hormon $\mathrm{rGH} 2,5 \mathrm{mg} / \mathrm{kg}$ pakan yaitu $0.60 \mathrm{gr}$. Kemudian diikuti perlakuan $\mathrm{C}$ dengan penambahan hormon $\mathrm{T}_{4} 20 \mathrm{mg} / \mathrm{kg}$ dan hormon $\mathrm{rGH} 2 \mathrm{mg} / \mathrm{kg}$ pakan yaitu $0.59 \mathrm{gr}$, dan pertumbuhan bobot selanjutnya pada perlakuan $B \mathrm{~T}_{4} 15 \mathrm{mg} / \mathrm{kg}$ dan hormon $\mathrm{rGH} 1,5 \mathrm{mg} / \mathrm{kg}$ pakan yaitu $0.46 \mathrm{gr}$, sedangkan terendah pada perlakuan $A$ (kontrol) tanpa menggunakan hormon yaitu $0,45 \mathrm{gr}$. Perlakuan $D$ merupakan pertumbuhan bobot yang sangat baik dan sesuai dengan perkembangan ikan koi yang saya teliti dengan jumlah waktu 45 hari. Menurut Alwi (2014) bahwa perlakuan dengan dosis tertinggi $25 \mathrm{mg} / \mathrm{kg}$ pakan menghasilkan pertumbuhan maksimal dengan bobot mencapai 4,96 gr pada ikan blackghost terjadi akibat metabolisme tubuh ikan yang bekerja secara baik setelah ikan mengkonsumsi pakan yang mengandung hormon.

Pada penelitian ini menunjukkan bahwa dengan penambahan hormon tiroksin dan rGH dengan metode oral tidak berpengaruh terhadap pertumbuhan bobot rata-rata benih ikan koi. Hal ini diduga dosis yang diberikan terlalu sedikit jika mengacu pada penelitian Zairin et al. (2005) yang menggunakan ikan plati koral sebagai hewan uji, seperti yang diketahui bahwa ikan tersebut merupakan golongan ikan ukuran kecil, oleh karena itu dosis yang digunakan harusnya lebih tinggi dikarenakan ikan koi merupakan golongan ikan ukuran besar.

Namun demikian dapat dilihat bahwa pertumbuhan pada perlakuan yang mengandung hormon lebih tinggi dibandingkan perlakuan yang tidak mengandung hormon (kontrol). Hal ini dikarenakan pemberian rekombinan hormon pertumbuhan dapat membantu laju pertumbuhan ikan menjadi lebih cepat dan tingkat konsumsi pakan yang di manfaatkan secara efektif dan optimal oleh ikan sehingga pakan yang diberikan benar-benar dimanfaatkan sebagai asupan nutrisi ikan yang diperlukan untuk pertumbuhannya, hal ini dapat dilihat dari ukuran ikan yang diberikan pakan rGH tubuhnya cenderung lebih bulat dan berisi, sedangkan yang tidak diberikan pakan rGH terlihat lonjong dan kurus. Hal ini sejalan dengan Peterson et al. (2004) dan Raven et al. (2012) pemberian rGH dapat meningkatkan laju pertumbuhan ikan dengan cara memperbaiki kinerja dari metabolisme nutrien dalam tubuh ikan dan dapat meningkatkan tingkat konsumsi pakan.

Pemberian $\mathrm{rGH}$ dengan metode oral diduga masuk ke dalam tubuh melalui sistem pencernaan dan merangsang kelenjar pituitary untuk memproduksi GH dalam jumlah yang lebih banyak, selanjutnya $\mathrm{GH}$ disalurkan melalui sistem peredaran darah menuju ke organ target yaitu jantung, hati, tulang, otot. Pemanfaatan pakan yang mengandung $\mathrm{rGH}$ dapat menstimulasi pertumbuhan ikan dan terbukti dapat meningkatkan laju pertumbuhan ikan jika dibandingkan dengan ikan kontrol tanpa pemberian rGH (Ben-Atia et al., 1999).

Hormon tiroksin dapat meningkatkan aktivitas protease dan lipase pada saluran pencernaan sehingga dapat meningkatkan metabolisme protein dan lemak dalam tubuh. Protease merupakan enzim yang menghidrolisis protein menjadi asam-asam amino dan peptida sederhana, sedangkan lipase merupakan enzim yang menghidrolisis lemak menjadi gliserol dan asam lemak yang kemudian akan diabsobrsi melalui dinding usus. Dengan demikian, pemberian rekombinasi hormon diduga mengaktivasi enzim-enzim pencernaan benih ikan koi dan pada akhirnya meningkatkan pertumbuhannya. Hidayat (2013) mengatakan bahwa peningkatan pertumbuhan yang cepat pada ikan dengan pemberian hormon tiroksin ini karena hormon yang diberikan dapat merangsang sistem syaraf pusat yaitu hypothalamus dan merangsang adenohypophysis yang mengandung hormon tyrotropik yaitu TSH untuk mengaktifkan kelenjar tyroid pada ikan sehingga kelenjar tyroid mengumpulkan iodine mensenyawakan dengan tyrosil yang diberikan lalu mengaktifkan metabolisme ikan. Karena metabolisme pada ikan berjalan dengan baik maka nafsu makan meningkat dan mengakibatkan pertumbuhan meningkat pula.

Hasil analisis data menunjukkan bahwa pertumbuhan bobot ikan koi adalah tidak berpengaruh nyata $F$ hit (1.331) < F tabel 0.01 (7.59) terhadap pertumbuhan ikan koi. Data penelitian menunjukkan bahwa pertumbuhan bobot terbaik terjadi pada perlakuan $\mathrm{D}$ dengan penambahan tiroksin dan $\mathrm{rGH}$ dalam pakan dibandingkan dengan perlakuan yang lain.

\subsubsection{Pertumbuhan panjang ikan koi}

Berdasarkan hasil penelitian selama 45 hari bahwa dengan penambahan hormon tiroksin dan $\mathrm{rGH}$ kedalam pakan terhadap pertumbuhan panjang rata-rata ikan koi dapat dilihat pada Gambar 2. Rata-rata pertumbuhan panjang ikan koi tertinggi pada perlakuan $\mathrm{D}$ dengan penambahan ke dalam pakan $\mathrm{T}_{4} 25 \mathrm{mg} / \mathrm{kg}$ dan hormon $\mathrm{rGH} 2,5 \mathrm{mg} / \mathrm{kg}$ pakan yaitu $0.54 \mathrm{~cm}$ dan pertumbuhan selanjutnya pada perlakuan $C$ dengan pambahan hormon sebanyak $\mathrm{T}_{4} 20 \mathrm{mg} / \mathrm{kg}$ dan hormon $\mathrm{rGH} 2 \mathrm{mg} / \mathrm{kg}$ pakan yaitu $0.50 \mathrm{~cm}$ dan selanjutnya pada perlakuan $\mathrm{B}$ dengan penambahan hormon $\mathrm{T}_{4} 15 \mathrm{mg} / \mathrm{kg}$ dan hormon $\mathrm{rGH} 1,5 \mathrm{mg} / \mathrm{kg}$ pakan yaitu $0.48 \mathrm{~cm}$, kemudian yang terakhir pertumbuhan panjang terendah pada perlakuan A dengan perlakuan kontrol yaitu dengan panjang $0.43 \mathrm{~cm}$. Dapat disimpulkan bahwa perlakuan terbaik adalah terdapat pada perlakuan D. Hasil ini diduga tidak terlepas dari pengaruh kombinasi $\mathrm{rGH}$ dan tiroksin dalam pakan dengan kadar protein tinggi yang mempengaruhi proses metabolisme tubuh, dalam mencerna dan menyerap 
pakan protein tinggi secara maksimal untuk dapat digunakan dalam proses pertumbuhan sehingga dapat meningkatkan pertumbuhan, dalam hal ini khususnya dapat meningkatkan pertumbuhan terutama nilai panjang total benih ikan koi. Ditambahkan pula pemberian $\mathrm{rGH}$ pada pakan dapat merangsang peningkatan produksi endogeneous hormone dalam tubuh benih ikan koi yang mempengaruhi proses metabolisme tubuh benih ikan koi seperti thyroid hormone dan ghrelin (Wong et al., 2006).

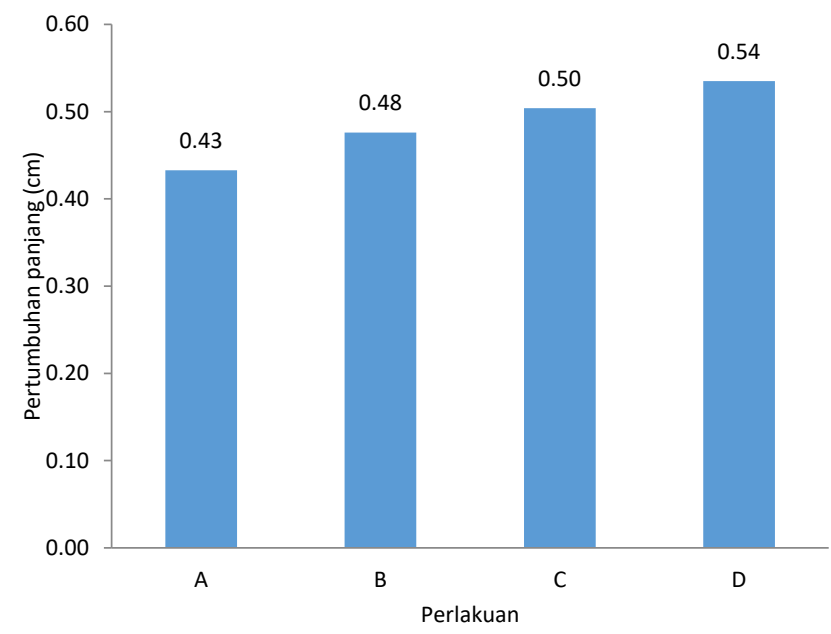

Gambar 2. Pertumbuhan panjang ikan koi.

Keterangan:

$A=$ kontrol

$B=\mathrm{T}_{4} 15 \mathrm{mg} / \mathrm{kg}, \mathrm{rGH} 1,5 \mathrm{mg} / \mathrm{kg}$

$\mathrm{C}=\mathrm{T}_{4} 20 \mathrm{mg} / \mathrm{kg}, \mathrm{rGH} 2 \mathrm{mg} / \mathrm{kg}$

$\mathrm{D}=\mathrm{T}_{4} 25 \mathrm{mg} / \mathrm{kg}, \mathrm{rGH} 2,5 \mathrm{mg} / \mathrm{kg}$

Hasil analisis data menyimpulkan bahwa hormon tiroksin dan $\mathrm{rGH}$ tidak berpengaruh nyata $\mathrm{F}$ hitung $(1.164)<\mathrm{F}$ tabel 0.01 (7.59). Hal ini diakibatkan ikan koi tidak mampu memanfaatkan pakan yang mengandung hormon tiroksin dan $\mathrm{rGH}$ yang berada dalam tubuhnya.

\subsection{Kelangsungan hidup (survival rate) ikan koi}

Berdasarkan penelitian yang dilakukan selama 45 hari menunjukkan bahwa penambahan hormon tiroksin dan $\mathrm{rGH}$ yang dicampurkan dalam pakan terhadap kelangsungan hidup ikan koi tidak mengalami perbedaan, dimana pada perlakuan $A$. kontrol; B. dosis $\mathrm{T}_{4} 15 \mathrm{mg} / \mathrm{kg}$ dan hormon $\mathrm{rGH}$ 1,5 mg/kg pakan; C. dosis $\mathrm{T}_{4} 20 \mathrm{mg} / \mathrm{kg}$ dan hormon $\mathrm{rGH} 2 \mathrm{mg} / \mathrm{kg}$ pakan; $\mathrm{D}$. dosis $\mathrm{T}_{4}$ $25 \mathrm{mg} / \mathrm{kg}$ dan hormon $\mathrm{rGH} 2,5 \mathrm{mg} / \mathrm{kg}$ pakan. Hasil penelitian menunjukkan bahwa perbedaan konsentrasi hormon tiroksin dan rGH tidak berpengaruh nyata terhadap kelangsungan hidup ikan koi. Kelangsungan hidup ikan koi pada akhir pemeliharaan dengan persentase yang didapat masing-masing yaitu $100 \%$. Hal ini pada saat penelitian tidak ada ikan yang mangalami kematian. Menurut Hidayat (2012) berpendapat bahwa dengan semakin baik metabolisme dalam tubuh ikan maka selera makan meningkat, daya tahan tubuh ikan terhadap lingkungan sekitarnya akan semakin baik sehingga mortalitas ikan lebih kecil. Hal ini disebabkan pemberian hormon yang dicampurkan pada pakan ikan koi sangat ditoleransi oleh perkembangan dan kelangsungan hidup ikan koi.

\subsection{Konversi pakan ikan koi}

Berdasarkan hasil penelitian 45 hari yang dilakukan ratarata nilai konversi pakan untuk masing-masing perlakuan dapat dilihat pada Gambar 3.

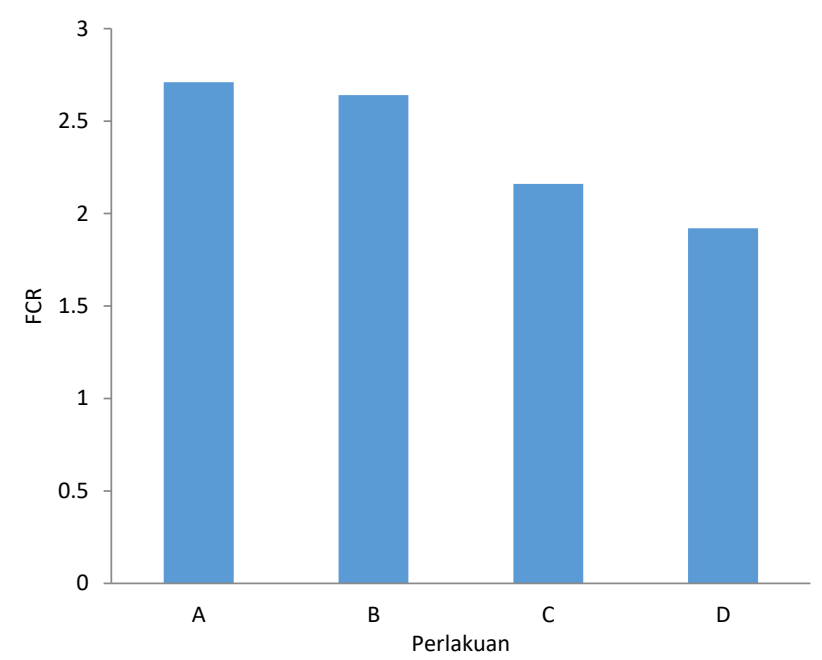

Gambar 3. Konversi pakan.

Keterangan:

$A=$ kontrol

$B=T_{4} 15 \mathrm{mg} / \mathrm{kg}, \mathrm{rGH} 1,5 \mathrm{mg} / \mathrm{kg}$

$\mathrm{C}=\mathrm{T}_{4} 20 \mathrm{mg} / \mathrm{kg}, \mathrm{rGH} 2 \mathrm{mg} / \mathrm{kg}$

$\mathrm{D}=\mathrm{T}_{4} 25 \mathrm{mg} / \mathrm{kg}, \mathrm{rGH} 2,5 \mathrm{mg} / \mathrm{kg}$

Berdasarkan hasil perhitungan nilai FCR pada benih ikan koi maka didapat nilai FCR pada perlakuan A yaitu 2, 71 gr, perlakuan B yaitu 2, $64 \mathrm{gr}$, perlakuan C yaitu 2,16 dan perlakuan D yaitu 1,92 gr. Hasil tersebut maka didapat nilai FCR terbaik terdapat pada perlakuan D (nilai terkecil) yaitu 1,92 gr, untuk meningkatkan $1 \mathrm{~kg}$ bobot ikan membutuhkan pakan 1,92 gr. Sedangkan konversi pakan yang kurang baik (nilai terbesar) terdapat pada perlakuan A (kontrol) yaitu 2,71 gr. Hal ini dapat disimpulkan bahwa untuk meningkatkan $1 \mathrm{~kg}$ ikan membutuhkan pakan 2,71 gr. Pakan sangat berperan penting terhadap perkembangan ikan koi pakan yang baik memiliki komposisi zat gizi yang lengkap dan baik terhadap penyerapan protein sepert lemak, karbohidrat, mineral dan vitamin, hormon juga menunda katabolisme asam-asam amino dan memacu pertumbuhan dalam protein-protein tubuh ikan koi. (Handoyo, 2012)

Konversi pakan merupakan perbandingan antara jumlah pakan yang diberikan dengan jumlah bobot yang dihasilkan. Menurut Effendi (2004), Feed Conversion Ratio (FCR) adalah suatu ukuran yang menyatakan ratio jumlah pakan yang dibutuhkan untuk menghasilkan $1 \mathrm{~kg}$ bobot ikan. Semakin kecil nilai konversi pakan maka tingkat efisiensi pemanfaatan pakan lebih baik. Sebaliknya apabila konversi pakan besar maka tingkat efisiensi pemanfaatan pakan kurang baik. Maka hal ini konversi pakan menggambarkan tingkat efisiensi pemanfaatan pakan yang dicapai. Hasil analisis menunjukkan bahwa hormon tiroksin dan $\mathrm{rGH}$ tidak berpengaruh nyata terhadap konversi pakan dengan $\mathrm{F}$ hitung (1.403) < F tabel 0.01 (7.59).

\subsection{Parameter kualitas air}

Kualitas air merupakan variabel yang sangat menentukan serta dapat mempengaruhi tingkat pertumbuhan panjang, bobot, dan kelangsungan hidup ikan koi. Pada saat penelitian yang dilakukan selama 45 hari parameter kualitas air yang di ukur adalah suhu, $\mathrm{pH}$ dan oksigen terlarut (DO) yang diukur setiap hari. Sedangkan amoniak hanya diukur tiga kali yaitu awal penelitian, pertengahan dan diakhir penelitian. Parameter kualitas air selama penelitian dapat dilihat pada Tabel 2 .

Kisaran kualitas air selama penelitian sangat mendukung untuk kehidupan ikan koi. Nilai suhu air yang diperoleh selama penelitian berkisar antara $27-28 \stackrel{\circ}{-}$. Hal ini sesuai dengan pendapat Fista (2003), bahwa kisaran suhu optimal untuk kehidupan dan perkembangan organisme perairan berkisar 
antara $25-35{ }^{\circ} \mathrm{C}$. Suhu mempunyai peranan penting dalam aktifitas perkembangan ikan koi peningkatan suhu lebih tinggi akan menurunkan aktivitas enzim. Yusriah dan Nengah (2013). Enzim mengalami perubahan kenfermasi pada suhu yang terlalu tinggi, sehingga terhambat dalam memasuki sisi perubahan aktif enzim. Pada dasarnya suhu yang dapat mematikan bagi biota bukan suhu yang ektrim tetapi perubahan suhu secara mendadak dari suhu alami yang menyebabkan kematian. Seperti dikemukakan Supriharyono (2010). Pengaruh peningkatan suhu perairan yang sangat derastis dapat menurunkan pada ketersediaan oxygen terlarut.

Tabel 2.

Kisaran parameter kualitas air

\begin{tabular}{lc}
\hline \multicolumn{1}{c}{ Parameter yang diamati } & Kisaran \\
\hline Suhu ${ }^{0} \mathrm{C}$ & $27-28$ \\
$\mathrm{pH}$ & $7.0-7.9$ \\
DO (ppm) & $5.9-6.9$ \\
Amonia (ppm) & $0,0359-0,1946$ \\
\hline
\end{tabular}

Sedangkan nilai $\mathrm{pH}$ air yang diperoleh selama penelitian berkisar antara 7,0-7,9. pH air yang diperoleh cenderung netral dan baik untuk pertumbuhan ikan. nilai $\mathrm{pH}$ ini sudah termasuk dalam $\mathrm{pH}$ yang sangat optimal untuk kelangsungan dan pertumbuhan ikan koi. Nilai pH menunjukkan derajat keasaman atau kebasaan suatu perairan yang dipengaruhi oleh garamgaram karbonat dan bikarbonat dalam perairan. Keberadaan $\mathrm{pH}$ berperan sebagai sistem penyangga keseimbangan senyawasenyawa kimia (Atkinson et al. (1995) dalam Sadarun (1999))

Nilai oksigen terlarut dalam air (DO) yang diperoleh selama penelitian berkisar antara 5,9-6,9 ppm. Oksigen terlarut (DO) berupa salah satu faktor penting dalam pemeliharaan ikan koi DO selama penelitian Semakin tinggi nilai DO dalam air menunjukkan bahwa air tersebut memiliki kualitas yang baik untuk pemeliharaan ikan. Kisaran parameter kualitas air yang masih dapat ditoleransi oleh ikan adalah suhu $20-28{ }^{\circ} \mathrm{C}, \mathrm{pH} 4,0-$ 6,0 dan 02 terlarut 2-8 ppm optimumnya 5-6 ppm (Azila, 2010).

\section{Kesimpulan}

Pemberian pakan yang mengandung hormon tiroksin dan rGH dengan metode oral dengan dosis yang berbeda tidak berpengaruh nyata terhadap pertambahan bobot, panjang dan kelangsungan hidup ikan koi. Pertumbuhan bobot dan panjang benih ikan koi terbaik yaitu perlakuan $D$ dengan dosis tiroksin 25 $\mathrm{mg} / \mathrm{kg}$ dan hormon $\mathrm{rGH} 2,5 \mathrm{mg} / \mathrm{kg}$ sebesar $0,60 \mathrm{gr}$ dan panjang $0,54 \mathrm{~cm}$. Tingkat kelangsungan hidup mempunyai rata $100 \%$. Hasil pengukuran nilai kualitas air selama penelitian yaitu suhu 27-28 ${ }^{\circ} \mathrm{C}$, pH 7,0-7,9, DO 5,9-6,9 ppm, amonia 0,0359-0,1946 ppm, nilai ini sangat baik untuk pertumbuhan dan kelangsungan hidup ikan koi. Pada perlakuan D jumlah pakan yang dihabiskan yaitu 1,92 gr. Berarti untuk meningkatkan 1 gr ikan menghabiskan pakan 1,92 gr.

\section{Bibliografi}

Alwi, D. A., 2014. Pengruh Pemberian Hormon Tiroksin Terhadap Pertumbuhan Dan Kelangsungan Hidup Ikan Blackghost ( Apteronotus albifrons). Skripsi. Fakultas Pertanian. Universitas Sumatera Utara, Sumatera Utara.

Bachtiar, Y. dan Tim Lentera, 2002. Mencegah Ikan Hias Mudah Mati. Agromedia Pustaka. Bogor.

Ben-Atia, I., Fine, M., Tandler, A., Funkenstein, B., Maurice, S., Cavari, B. and Gertler, A., 1999. Preparation of
Recombinant Gilthead Seabream (Sparus aurata) Growth Hormone and its Use for Stimulation of Larvae Growth by Oral Administration. Gen Comp Endocr 113: 155-164.

Effendie, M.I., 1979. Biologi Perikanan. Yayasan Pustaka Nusatama, Yogyakarta.

Effendi, I., 2004. Pengantar Akuakultur. Penebar Swadaya. Jakarta.

Effendy, H., 1993. Mengenal Beberapa Jenis Koi. Kanisius. Yogyakarta.

Fista, E., 2003. Struktur Komunitas Plankton di Perairan Danau Di Atas Kabupaten Solok Sumatera Barat. Skripsi. FKIP UR, Pekanbaru.

Gomez, K.A dan Gomez, A.A., 1995. Prosedur Statistik untuk Penelitian Pertanian. Edisi Kedua. Penerjemah: E. Sjamsuddin dan J. S. Baharsjah. Penerbit Universitas Indonesia. 689 hal. Jakarta.

Handoyo, B, Alimuddin, Utomo, N.B.P., 2012. Pertumbuhan, Konversi dan Retensi Pakan, dan Proksimat tubuh benih ikan sidat yang diberi hormon pertumbuhan rekombinan ikan kerapu kertang melalui perendaman. Jurnal akuakultur indonesia. 2: 132-140.

Hidayat, R., 2012. Enlargement of Selais (Ompok hypopthalmus) With Fish Meal Containing Thyroxine (T4) Hormones. Skripsi. Fakultas Perikanan dan IImu Kelautan. Universitas Riau, Riau.

Hidayat, K., 2013. Pembesaran Ikan Selais (Ompok hypopthalmus) dengan Pemberian Pakan yang Mengandung Hormon Tiroksin (T4). Skripsi. Fakultas Perikanan dan Ilmu Kelautan Universitas Riau. Pekanbaru. 50 hal. (tidak diterbitkan)

Huisman, E. A., 1976. Food convertion efficiency at maintenance and production for common carp, Cyprinus carpio, and rainbow trout, Salmon gairdneri. Aquaculture, 9: 259273.

Ihsanudin, T., 2014. Pengaruh Pemberian Rekombinan Hormon Pertumbuhan (rGH) Melalui Metode Oral Dengan Interval Waktu Yang Berbeda Terhadap Pertumbuhan Dan Kelulushidupan Benih Ikan Nila Larasati (Oreochromis niloticus). Jurnal. Perikanan dan Ilmu Kelautan, Universitas Diponegoro, Semarang.

Peterson, B.C, Small, B. C, Bosworth B.G., 2004. Effect of Bovine Growth Hormon (Posilac) on Growth Performance, Body Composition, and IGFBPs in Two Strain of Channel Catfish. Aquacultur 232:651-663.

Sadarun, 1999. Pengaruh Pemberian Hormon Tiroksin Secara Oral Terhadap Pertumbuhan dan Kelangsungan Hidup Ikan Plati Koral (Xiphoporus maculates). Jurnal Akuakultur Indonesia, 4(1) : 31-35.

Supriharyono, 2010. Pengaruh Pemberian Recombinant Growth Hormone ( $\mathrm{rGH}$ ) Melalui Metode Oral Dengan Interval Waktu Yang Berbeda Terhadap Kelulushidupan dan Pertumbuhan Larva Ikan Gurame var Bastard 
(Osphronemus gouramy Lac, 1801). Jurnal Perikanan dan Ilmu Kelautan, Universitas Diponegoro, Semarang.

Wong, A.O.L., Hong, Z., Yonghua, J., Wendy, K.W.K.O., 2006. Feedback Regulation of Growth Hormone Synthesis and Secretion in Fish and the Emerging Concept of Inpituitary Feedback Loop. Comparative Biochemistry and Physiology Part A. 144, 284-305.

Yusriah, dan Nengah, D.K., 2013. Pengaruh pH dan Suhu Terhadap Aktivitas Protease Penicillium sp. Jurnal Sains dan Seni Pomits Vol. 2, No.1, (2013) 22337-3520.

Zairin, M. Jr., Pahlawan, R.G dan Raswin, M., 2005. Pengaruh Pemberian Hormon Tiroksin Secara Oral Terhadap Pertumbuhan dan Kelangsungan Hidup Ikan Plati Koral (Xiphoporus maculates). Jurnal Akuakultur Indonesia, 4(1): 31-35. 